\title{
The Towuti Drilling Project: Paleoenvironments, Biological Evolution, and Geomicrobiology of a Tropical Pacific Lake
}

\author{
by James Russell and Satria Bijaksana
}

doi:10.2204/iodp.sd.14.11.2012

\section{Introduction}

Three zones of deep atmospheric convection energize the Earth's heat and moisture budgets: tropical Africa, Amazonia, and the Indo-Pacific. The Indo-Pacific region is by far the largest and most important of these (Fig. 1), and it exerts an enormous influence on global climate (Pierrehumbert, 1999). Lacustrine scientific drilling through International Continental Scientific Drillig Program (ICDP) has provided a suite of lake records from the northern and southern tropics (Fig. 1), providing key insights into the mechanisms responsible for long-term variations in the monsoons at the modern-day limits of the seasonal migration of the Intertropical Convergence Zone (ITCZ) in South America, Africa, and Asia (Fritz et al., 2007; Hodell et al., 2007; Scholz et al., 2007). However, ICDP has not yet provided a long climate record from an equatorial zone of deep convection, nor from the tropical western Pacific.

Lake Towuti $\left(2.75^{\circ} \mathrm{S}, 121.5^{\circ} \mathrm{E}, 561 \mathrm{~km}^{2}, 203 \mathrm{~m}\right.$ maximum depth) is the largest tectonic lake in Indonesia, and it is part of the Malili lake system, a set of five, ancient (1-2 Myr) tectonic lakes in central Sulawesi (Fig. 2). Lake Towuti's location in central Indonesia provides a unique opportunity to reconstruct paleoclimates and paleoenvironments in the crucially important yet understudied Indo-Pacific Warm Pool (IPWP). Moreover, the Malili lakes have extremely high rates of floral and faunal endemism and are surrounded by one of the most diverse tropical forests on Earth. Drilling in Lake Towuti will document the environmental and climatic context that shaped the evolution of Malili's unique lacustrine and terrestrial ecosystems and their resilience to long-term environmental change. Lake Towuti is surrounded by ultrabasic (ophiolitic) rocks that release high levels of iron, nickel, chromium, and other metals, catalyzing biogeochemical reactions within a diverse, exotic microbial community. Drill core will provide insight into long-term changes in the geomicrobiology of this system, including coupled changes in climate, microbial biogeochemical cycling, carbon storage, metal deposition, and microbial processes operating at depth in the sediment.

\section{Site Description}

The clear potential of Lake Towuti to the scientific drilling community was recognized already in 1995 by the Past Global Changes (PAGES) workshop on Continental Drilling for Paleoclimate Records, which designated the Malili Lakes a high-priority drilling target (Colman, 1996). However, only now do we have the requisite site survey information to begin planning a drilling program on Lake Towuti. Over the course of four field seasons we have acquired 150 meters of sediment core and over a thousand kilometers of CHIRP and airgun seismic reflection data, such that we can now propose the first lake drilling project in Southeast Asia.

Existing sediment cores (10-15 m long) from Lake Towuti reveal large variations in sedimentation at millennial and longer time scales during the past $60 \mathrm{kyr}$. Variations in sediment metal content are associated with large variations in paleohydrology. These are measured by isotopic indicators, changes in vege- 


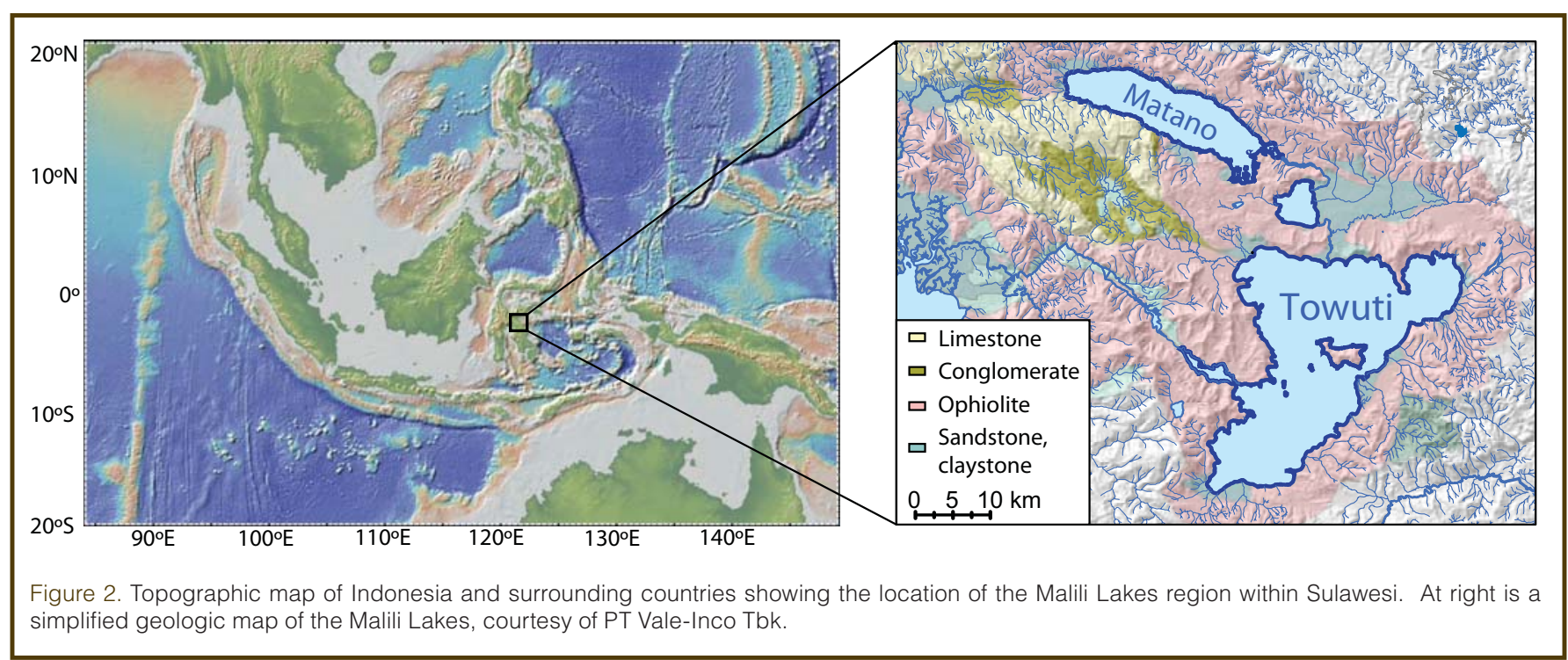

tation observed through fossil pollen, as well as substantial variations in sedimentary organic carbon content and other indicators of lacustrine carbon cycling. All of these indicate coherent linkages between climate, ecosystems, and lacustrine geomicrobiology.

Seismic reflection data document up to 150 meters of stratified lacustrine fill in the basin (Fig. 3), likely spanning the last $\sim 700,000$ years. With this abundance of lacustrine sediment, we can test the response of IPWP hydrology across glacial-interglacial variations since the mid-Pleistocene transition. This lacustrine unit is underlain by fluviolacustrine material of a similar thickness that records the history of initial infilling and structural evolution of the Towuti basin. There is no evidence for widespread gas that could pose a drilling hazard, nor extensive tectonic deformation of these sediments; these conditions allow us to optimize our coring locations for critical science objectives. This dynamic setting provides the context in which our science groups developed their hypotheses and questions.

Lake Towuti's climate is influenced by the Australasian monsoons, changes in the Walker Circulation driven from both the Indian and Pacific Oceans, and the location and strength of convection within the ITCZ. Lake level monitoring shows a strong influence of the El Niño-Southern Oscillation (ENSO), and while sediments from Towuti cannot resolve individual El Niño events, the long-term climate variability of Sulawesi is governed by the interplay between meridional monsoon variations and zonally-oriented anomalies that originate in the Walker circulation. Lake Towuti is hosted within a fault-bounded extensional basin along the Matano-Palu Fault, a strike-slip fault system formed in association with the collision between Australia and Eurasia. Bedrock is dominated by the large East Sulawesi Ophiolite (Kadarusman et al., 2004). Lateritic nickel ores that developed on these ultrabasic rocks have attracted the mining industry, with whom we will partner in our proposed work.

\section{Workshop Structure and Findings}

To develop the Towuti Coring Project, sixty-two people from nine countries participated in a workshop in Bandung, Indonesia during 26-29 March 2012 to define scientific priorities and logistical demands for deep scientific drilling in Lake Towuti. Presentations on the first day focused on IPWP climate dynamics and history, the structural geological evolution of Sulawesi, and the limnology, geomicrobiology, and evolutionary biology of the lake. Participants spent the following three days in breakout groups to focus on developing the scientific hypotheses and strategies, with breakout groups divided into five themes: paleoclimate, geochronology, geomicrobiology, evolutionary biology, and structural geology. Discussions during day 4 focused on drilling project logistics, planning, and timelines.

The paleoclimate group reviewed extensive data sets from mainland Asia documenting the long-term history of the Asian monsoon, highlighted by loess and speleothem records spanning hundreds of millennia (Wang et al., 2008). These records show a dominant response of the Asian monsoon to orbital precession, yet existing sediment cores from Lake Towuti highlight substantial changes in regional hydrology associated with the Last Glacial Maximum. Drilling long, 700,000-year sequences would allow us to test whether hydrological changes in central Indonesia are driven by tropical insolation or glacial forcing across multiple glacial-interglacial cycles, including changes in the Walker Circulation forced by exposure of the Sunda Shelf and greenhouse gas variations (DiNezio et al., 2011). We could also investigate the amplitude of land surface temperature changes across multiple glacial cycles, its relation to temperature, and the extent to which high-latitude events such as Heinrich and Dansgaard/Oeschger variability influence the hydrology of the maritime continent.

The Malili lakes are ultraoligotrophic systems that contain a unique and fascinating microbial community (Crowe 
et al., 2008) that dominates the lakes' biology. At present, the high metal and low sulfur content of lake water and sediments fuel a geomicrobiological community in these lakes driven largely by metal cycling. Existing sediment cores suggest large changes in metal deposition through time, with possible impacts on microbial composition, activity, and the lacustrine carbon cycle. Through drilling, we will investigate long-term rates of microbial evolution and ecosystem

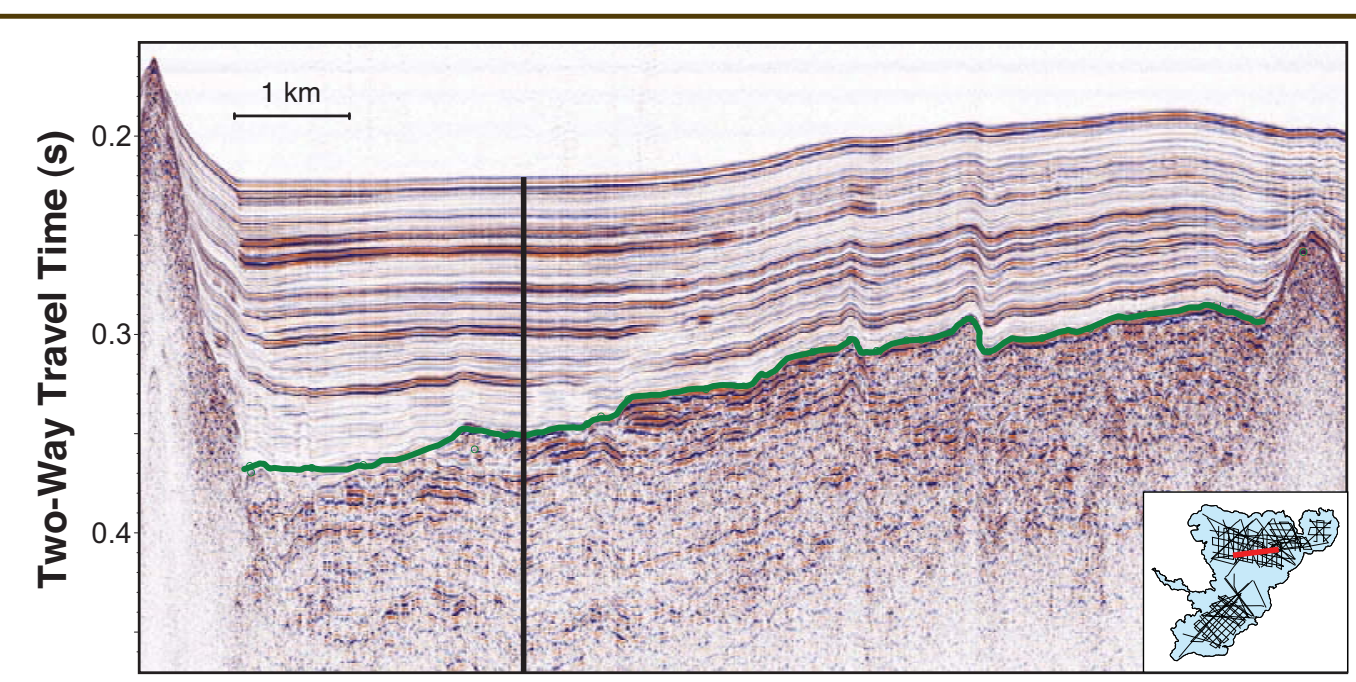

Figure 3. Example of seismic section from northern Lake Towuti (Wattrus et al, unpublished). Inset at bottom right indicates the location of this section (thick red line) within our seismic reflection grid (thin black lines). The boundary between stratified lacustrine sediment (upper unit) and fluviolacustrine sediment (lower unit) is marked by a green line. One hypothetical drilling target is illustrated by the black line. change in a ferruginous

basin. We will further investigate how external forcingincluding changes in chemical and physical weathering of the landscape, terrestrial geomorphology, and climate-driven changesinlake mixing-affects Towuti's geomicro-biological community and sediment geochemistry. Indeed, this work will provide important constraints on the behavior of sediment climate proxies in metal-rich, organic carbon-poor sediments

Lake Towuti is the largest of the Malili Lakes complex, and is situated at the downstream end, with flow from Lake Matano through Lake Mahalona into Towuti. Sarasin and Sarasin (1895) were among the first Western scientists to explore the Malili Lakes, and they noted the lakes' unique fauna. Subsequent work during the twentieth century confirmed the presence of diverse, highly endemic flora and fauna in the Malili Lakes (Rintelen et al., 2011), and data have shown that each of the Malili Lakes contain a locally

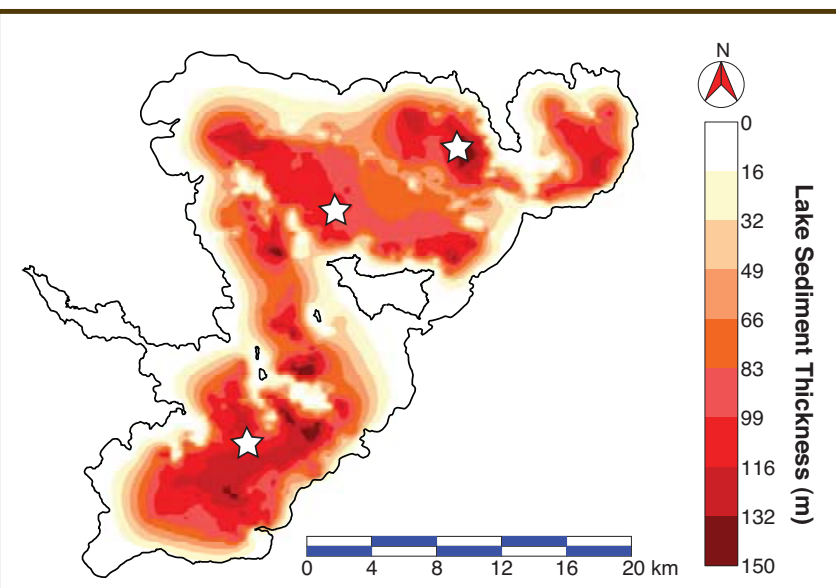

Figure 4. Coring targets (indicated by stars) overlain on a map of the thickness of stratified lacustrine sediment (Wattrus and Russell, unpublished). endemic fauna despite the hydrologic connections between the basin. This could hint at long-term changes in the hydrologic connectivity among these lakes related to movement along the region's numerous and active faults. Drilling in Lake Towuti will allow us to investigate whether tectonic evolution of the Malili Lakes' drainages influenced the timing, rate, and mode of speciation in these basins. Drilling will also elucidate the sensitivity and resilience of central Sulawesi's rainforests to climate, fire, and environmental variability.

Investigations of these areas will require a robust geochronology. The high iron and magnetic mineral content, coupled with little reductive diagenesis, makes Towuti an ideal site for dating sediment cores through paleomagnetic variations. Existing paleointensity data show robust correlation to reference sections from the Sulu Sea (Schneider and Mello, 1996), placing the Towuti chronology on the marine oxygen isotope time scale. Although Towuti is far from major volcanoes, ashes likely derived from the North Sulawesi volcanic field are present in sediment cores and appear common in seismic reflection data. These could provide additional constraint and may also provide a history of large-magnitude eruptions in a poorly studied region.

Participants discussed possible drilling targets to address these issues and whether to drill both the lacustrine and fluviolacustrine sections in Towuti. Participants agreed on the importance of recovering a complete lacustrine and fluviolacustrine section to improve our understanding of the biological and environmental evolution of the Towuti basin. Through these discussions, three primary drilling targets (Fig. 4) were identified: 
- a primary site in central Towuti where existing sediment cores and seismic data indicate the most quiescent depositional setting,

- a site situated in northern Towuti to record variations in sediment input from the Mahalona River, to reconstruct the hydrological connectivity of the Malili system, and

- a site in southern Towuti, which is completely dominated by ultramafic rocks and where some of the oldest lacustrine sediments are found.

We are now pursuing pre-drilling scientific activities including improved sedimentological surveys of the Towuti basin, limnological and climate monitoring, and educational and outreach activities within the local community.

\section{References}

Colman, S.M., 1996. Continental drilling for paleoclimatic records: Recommendations from an international workshop. PAGES Workshop Report Series, 96-4, 104 pp.

Crowe, S.A., O’Neill, A.H., Katsev, S., Hehanussa, P.E., Haffner, G.D., Sundby, B., Mucci, A., and Fowle, D.A., 2008. The biogeochemistry of tropical lakes: A case study from Lake Matano, Indonesia. Limnol. Oceanogr., 53:319-331, doi:10.4319/ 10.2008.53.1.0319

DiNezio, P.N., Clement, A.C., Vecchi, G.A., Soden, B.J., Broccoli, A.J., Otto-Bliesner, B., and Braconnot, P., 2011. The response of the Walker Circulation to LGM forcing: Implications for detection in proxies. Paleoceanography, 26:PA3217.

Fritz, S.C., Baker, P.A., Seltzer, G.O., Ballantyne, A., Tapia, P.M., Cheng, H., and Edwards, R. L., 2007. Quaternary glaciation and hydrologic variation in the South American tropics as reconstructed from the Lake Titicaca drilling project. Quat. Res., 68:410-420, doi:10.1016/j.yqres.2007.07.008

Hodell, D.A., Anselmetti, F.S., Ariztegui, D., Brenner, M., Curtis, J.H., Gilli, A., Grzesik, D., et al., 2007. An 85-ka record of climate change in lowland central America. Quat. Sci. Rev., 27:1152-1165, doi:10.1016/j.quascirev.2008.02.008

Kalnay, E., Kanamitsu, M., Kistler, R., Collins, W., Deaven, D., Gandin, L., Iredell, M., et al., 1996. The NCEP/NCAR 40-Year Reanalysis Project. Bull. Amer. Meteor. Soc., 77:437-471. doi:10.1175/1520-0477(1996)077<0437:TNYRP $>2.0 . \mathrm{CO} ; 2$

Kadarusman, A., Miyashita, S., Maruyama, S., Parkinson, C.D., and Ishikawa, A., 2004. Petrology, geochemistry, and paleogeographic reconstruction of the East Sulawesi Ophiolite, Indonesia. Tectonostratigraphy, 392:55-83, doi:10.1016. j.tecto.2004.04.008

Pierrehumbert, R.T., 1999. Subtropical water vapor as a mediator of rapid global climate changes. In Clark, P.U., Webb, R.S., and Keigwin, L.D. (Eds.), Mechanisms of Global Climate Change at Millennial Time Scales. Geophysical Monograph Series, 112: Washington, DC (American Geophysical Union), 339-361, doi:10.1029/GM112p0339

Rintelen, T.v., Rintelen, K.v., Glaubrecht, M., Schubart, C., and Herder, F., 2011. Aquatic biodiversity hotspots in Wallacea - the species flocks in the ancient lakes of Sulawesi, Indonesia. In Gower, D.J., Johnson, K.G., Richardson, J.E.,
Rosen, B.R., Rüber, L., and Williams, S.T. (Eds.), Biotic Evolution and Environmental Change in Southeast Asia: Cambridge (Cambridge University Press).

Sarasin, P., and Sarasin, F., 1895. Reisebericht aus Celebes. IV. Reise durch Central-Celebes vom Golf von Boni nach dem Golf von Tomieni. Verhandlungen der Gesellschaft für Erdkunde, 30:312-352.

Schneider, D.A., and Mello, G.A., 1996. A high-resolution marine sedimentary record of geomagnetic intensity during the Brunhes Chron. Earth Planet. Sci. Lett., 144:297-314, doi:10.1016/0012-821X(96)00164-1

Scholz, C., Johnson, T.C., Cohen, A.S., King, J.W., Peck, J.A., Overpeck, J.T., Talbot, M.R., et al., 2007. East African megadroughts between 135 and 75 thousand years ago and bearings on early-modern human origins. Proc. Natl. Acad. Sci. U.S.A., 42:16416-16421, doi:10.1073/pnas.0703874104

Wang, Y., Cheng, H., Edwards, R.L., Kong, X., Shao, X., Chen, S., Wu, J., Jiang, X., Wang, X., and An, Z., 2008. Millennial- and orbital-scale changes in the East Asian monsoon over the past 224,000 years. Nature, 451:1909-1093, doi:10.1038/ nature 06692

\section{Authors}

James Russell, Department of Geological Sciences, Brown University, Box 1846, Providence, RI 02912, U.S.A., e-mail: James_Russell@Brown.edu

Satria Bijaksana, Global Geophysics Research Group, Faculty of Mining and Petroleum Engineering, Institut Teknologi Bandung, Jalan Ganesa 10, Bandung, 40132, Indonesia, e-mail: satria@fi.itb.ac.id 